\title{
Time And Quality: Twin Keys To Customer Service Satisfaction
}

\author{
Dr. Sydney Roslow, Marketing \& Environment, Florida International University \\ Dr. J. A. F. Nicholls, Marketing \& Environment, Florida International University \\ Dr. John Tsalikis, Marketing \& Environment, Florida International University
}

\begin{abstract}
Customers expect satisfaction when employing a service. We have explored the applicability of two elements of service satisfaction: time and quality. The time element utilized two measures: consumption time and waiting time. The five elements of quality we utilized were: courtesy, attentiveness, ability, accuracy, professionalism. We found that the time factor was somewhat more significant than the quality factor in determining consumers, satisfaction in the service experience situation and in the service accomplishment. Although this study was based on banking services, the time and quality dimensions are generally present in all service industries.
\end{abstract}

\section{Introduction}

In consuming a product, the customer expects a satisfactory experience. This expectation is identical whether the product is a good or a service (Zeithaml 1981). In the purchase of goods, like an item of clothing, several different considerations enter into a consumer s satisfaction. These may include satisfaction with the fit, style, price, wearability, or even the attention it evokes. Similarly, this is true with the provision of a service, whether the service is educational, entertainment, financial, legal, medical, personal grooming, or hospitality. Each of these services comes with an array of attributes which may (or may not) be a source of satisfaction for an individual consumer. What is a source of satisfaction for one consumer, may (or may not) be a source of satisfaction for another.

Manufacturers are sensitive to the fact that sources of satisfaction vary among consumers and emphasize different product attributes in their promotions. For example, automobile manufacturers highlight different tangible and intangible features of their cars - reliability, style, comfort, economy, prestige, finish, and luxury. They do so because they realize they are serving different consumer segments which are interested in these different considerations. In effect, they meet their consumers' needs for these varying attributes. Similarly, service industries are faced with consumers who have a wide variety of needs to be satisfied (Barker and Gimple 1982; Kim, Farragher, and Guithues 1979). Since service industries provide intangible products, consumer satisfaction depends to a large measure on the customers' perceptions of "quality."

\section{The Quality Dimension}

These perceptual aspects of quality have been reported in numerous articles in the literature (Berry, Zeithaml, and Parasuraman 1985; Cravens, Dielman, and Harrington 1985; Crosby and Stephens 1987; Davis and Paul 1987; Day and Castleberry 1986; Feinholz 1986; Gronroos 1984). Quality perceptions can depend on both tangible and intangible elements, including the decor of business premises, or the "decor" of employees, how problems are handled in the provider-consumer interaction, the relationships established between the provider and the consumer, or what is expected compared to what is actually delivered (Garfein 1987). It is not surprising that service quality has become a major issue for companies and researchers in the United States.

In a seminal study, which developed a model of service quality, ten elements that contributed to satisfaction were identified (Parasuraman, Zeithaml, and Berry 1985):

$$
\begin{array}{ll}
* \text { reliability } & * \text { responsiveness } \\
* \text { competence } & * \text { access } \\
\text { * courtesy } & * \text { communication } \\
* \text { credibility } & * \text { security } \\
\text { * understanding } & * \text { tangibility }
\end{array}
$$

A service possessing these ten elements is likely to satisfy consumers' needs and be viewed as having high quality.

\section{The Time Dimension}

We find another common dimension in these elements of service satisfaction which is time. The time dimension inherent in the ten elements identified by Parasuraman, Zeithaml, and Berry are as follows:

Reliability: Performing the service when and where indicated. 
Responsiveness: Promptness of service.

Competence: "Knowledge and skill," one of the components of competence, either speeds up the service rendition and/or reduces the time demanded of the consumer.

Access: Waiting time to receive service is a major component of this determinant.

Courtesy: "Politeness, respect, consideration, and friendliness" facilitates the service routine which affects the customers' actual clock time and perception of time.

Communication: Efficient communication saves time.

Credibility: A reputation for trustworthiness, believability, and honesty reduces search time for an alternate supplier.

Security: Reduction of danger and risk eliminates timeconsuming security precautions.

Understanding: Learning the customer ${ }_{\imath}$ s specific requirements speeds service rendition.

Tangibility: Use of up-to-date equipment speeds service delivery.

Time can be conceptualized as having two phases. One is waiting time to receive the service, the other is time spent to consume the service. Other researchers have investigated these two dimensions of time. For example, in one (a study of bank choice), the most important characteristic of consumer selection of a bank was "friendly and efficient service," while one of much lower importance was "conveniently located branches and hours" (Gwin and Lindgren 1986). Although there is no separation of the role of waiting time and servicing time, the general importance of time is clear. In a Canadian banking study, savings and checking accounts were chosen on the basis of competitive rates and safety, ambiance and accessibility of the service, and location and automatic tellers (Larroche and Taylor 1988). Each of these, according to our previous analysis, can be viewed as having a time dimension. To reduce waiting time and the servicing time, banks must make their customers change their consumption habits in terms of demand time (Lovelock and Young 1979). This is evidently happening in the hours banks are open, whether in the evenings, over weekends, etc. According to one study, the affluent consumer, in particular, puts more emphasis on speedy loan decisions than on interest rates (Stanley, Moschis, and Danko 1987). When consumers want to reduce nuisance and hassle they may be willing to accept impersonal delivery service, such as automated teller machines (ATMs). "Having to deal with personal attention may even be a negative factor where the primary customer motivation is to save time and have efficient service" (Pollock 1985).
In a study of 1,000 service companies, strategies were proposed to deal with the problem of fluctuating demand created by peak time load (Zeithaml, Parasuraman, and Berry 1985). The strategies to cope with fluctuating demand were based on dealing with the time factor. For example, hiring extra full-time or part-time employees; differential employee scheduling during peak hours; care of regular customers, allowing others to wait; educate and offer incentives to customers to use service in non-peak hours.

As baby boomers mature, they will demand time and locational convenience, an end to traditional business hours, more automated services, and where automation is not feasible, they will prefer appointments rather than queuing, so as to save time. In effect, they "will continually seek to optimize their discretionary time" (Koehn 1986). Consumer behavior is being influenced by people's time pressures. Discretionary time is perceived as insufficient to accommodate all the demands on it, resulting in a "time-buying" consumer intent on preserving discretionary time (Berry 1980). Furthermore, all waiting time is not perceived to be alike. Certain forms of waiting seem more arduous than others. For example, unoccupied time seems longer than occupied time (Maister 1985).

"Inequitable waiting time and price both appeared to induce strong expectations of dissatisfaction and lower expectations of service quality" (Fisk 1980). This has led to ATM and Electronic Funds Transfer (EFT) systems and one-stop financial services as offered by Banc One in Columbus, Ohio.

One paper has punctured the popular myth that today's consumers enjoy more leisure time than before. Because of the prevalence of dual income households, consumers do, indeed, have higher money incomes than in previous generations. Increased money incomes have been bought, however, at the expense of leisure time. The higher a consumer's income, "the less discretionary or leisure time they are likely to have" (Blackwell and Hanke 1987). On the other hand, there is a concept of polychronic time (Lane 1988; Lane, Kaufman, Lindquist 1989). This concept postulates that individuals may make up for their dearth of time by packing more into a given period, performing more than one task simultaneously. This makes the concept of time poverty more of a psychological one than a physical one.

From the findings of the literature cited, the marketer can discover opportunities to address the customers, need to conserve time in achieving consumer satisfaction. In the process, marketers can learn to influence purchase decisions on the time plane and differentiate their service from those of competitors. For instance, some supermarkets promote the fact that they open up an additional check-out line when more than a given number of cus- 
tomers, usually three, are waiting in other lines. In the health care industry, providers are aware that their industry involves waiting for an appointment, waiting on the premises, as well as time required to render the health service. These waiting experiences affect the consumers. perception of the quality of the service.

\section{Background for Our Study}

In a mature industry, rivals copy product features of successful brands so that products become more and more alike (Schoell and Guiltinan 1990, pp. 306- 307). Increasingly, the major distinction between brands lies in their unique features. One unique feature is service quality. An aspect of service quality is access - easy to obtain, at a convenient time, and with a minimum of waiting (Kotler 1991, p. 464). Banking is an example of a mature industry, where competitors provide an intangible, essentially similar, service. Each bank needs to make sure that its customers are satisfied with its products. Most banks provide checking accounts, savings accounts, safe deposit boxes, ATM cards, loans, mortgages, securities transactions, and so forth. Therefore, an important differentiation in banking is in the quality of the service rendered, rather than the variety of services provided. Quality, however, is a subjective thing, existing in the mind of the consumer. For this reason, we chose to study customer satisfaction in the banking industry. The time elements of customer satisfaction that were investigated are: (1) waiting time and (2) service consumption time. The quality elements involved bank employee ‘s (3) courtesy, (4) attentiveness, (5) ability, (6) accuracy, and (7) professionalism.

Time savings are important to a bank, as well as to the consumer, for productivity and profitability. In the banking industry, for example, banking by mail was an early step in this direction. Mail transactions reduce the need of the consumer to come to the bank to make deposits involving a teller. More recently, the ATM eliminates the bank teller, s one-on-one relationship with the depositor. Telephones can be used to transfer funds from one account to another. There are, however, transactions which still warrant face-to-face meetings with bank representatives. These are classic examples of a service industry's simultaneous production and consumption process which in banking include: opening and closing a safe deposit box, applying for a loan, opening and closing various accounts.

\section{Method}

Our study sampled bank customers who had completed transactions over a specific six month period of time. The transactions were for five service experiences at six branches of the bank. The bank supplied the names and telephone numbers of its customers. A total of 1,058 respondents were surveyed, by telephone, constituting the sample for the five transactions. The sample sizes for each of the five transactions were:

* Application for an ATM card [ $\mathrm{n}=170]$

* Redemption of a CD account [ $\mathrm{n}=235]$

* Application for a loan [n=222]

* Opening a new bank account [ $\mathrm{n}=228]$

* Opening/closing a safe deposit box [n=203]

Two criteria of overall satisfaction were measured: the service experience and the service accomplishment. The degree of satisfaction with experience and accomplishment was phrased in two Likert-type attitudinal questions calling for a five-degree evaluation from "very satisfied" to "very dissatisfied" (Likert, Roslow, and Murphy 1934).

This same measurement technique was also utilized for the evaluation of seven specific elements of satisfaction for each transaction at the bank. The definitions of these elements of satisfaction for the time dimension were:

Waiting Time. The length of time between entering the bank, finding the service area, and waiting for the appropriate bank representative.

Service Consumption Time. The time it took to identify the service needed, get any explanation, and complete the paper work for the service.

For quality, the definitions were:

Courtesy. Customer's evaluation of the politeness and civility of the bank representative.

Attentiveness. Extent of the bank representative's concentration on the needs of the customer; minimum of interruptions, telephone or otherwise.

Ability. Bank representative's capability in answering questions fully and informatively.

Accuracy. Accurately of the bank representative in filling out the necessary forms.

Professionalism. How the bank's representative dealt with the customer during the transaction. Their appearance of knowledge, their projection of expertise.

A questionnaire was designed to collect these customer satisfaction ratings. The questionnaire also included demographic data such as age, sex, income, and employment status, as well as information concerning a customer's other holdings at the bank. The 1,058 sample was obtained from 1,367 completed telephone calls - a 77 per cent acceptance rate. 


\section{Results}

Our concept of customer satisfaction was viewed as having two dimensions . time and quality. In order to determine whether these two dimension were actually present in the data, a principal components factor analysis was performed (only factors with an eigenvalue higher than one were considered). A VARIMAX orthogonal rotation revealed two underlying dimensions/factors: (a) a "quality" factor (F1), composed of the customers' perceptions of the bank representatives' courtesy, attentiveness, ability, accuracy, and professionalism, and (b) a "time" factor (F2), composed of two distinct elements: waiting time and service consumption time (Table 1).
These particular factor loadings are true for 4 out of the 5 services. We do note a crossover of these elements in the factors relating to the ATM service, where waiting time variable loads in the quality factor (F1) and accuracy and ability crosses over to the time factor (F2). The former might be explained by the fact that ATM customers were significantly younger than customers of the other services, or that the consumption time for the application for an ATM card may have been different from the time required for the other services. Similarly, there is a crossover into the time factor in the case of accuracy in applying for new accounts. As pointed out earlier, accuracy is, in effect, an aspect of time.

\begin{tabular}{|c|c|c|}
\hline \multicolumn{3}{|c|}{$\begin{array}{l}\text { Table } 1 \\
\text { Results from the Factor Analysis }\end{array}$} \\
\hline Banking Transaction & Factor 1: Quality $(\mathrm{F} 1)^{\mathbf{a}}$ & Factor 2: Time (F2) \\
\hline ATM & $\begin{array}{l}\text { Attentiveness } \\
\text { Courtesy } \\
\text { Professionalism } \\
\text { Waiting time }\end{array}$ & $\begin{array}{l}\text { Service consumption time } \\
\text { Accuracy } \\
\text { Ability }\end{array}$ \\
\hline Loan & $\begin{array}{l}\text { Courtesy } \\
\text { Professionalism } \\
\text { Attentiveness } \\
\text { Ability } \\
\text { Accuracy }\end{array}$ & $\begin{array}{l}\text { Service consumption time } \\
\text { Waiting time }\end{array}$ \\
\hline New Account & $\begin{array}{l}\text { Attentiveness } \\
\text { Courtesy } \\
\text { Professionalism } \\
\text { Ability }\end{array}$ & $\begin{array}{l}\text { Service consumption time } \\
\text { Waiting time } \\
\text { Accuracy }\end{array}$ \\
\hline CD & $\begin{array}{l}\text { Courtesy } \\
\text { Professionalism } \\
\text { Ability } \\
\text { Attentiveness } \\
\text { Accuracy }\end{array}$ & $\begin{array}{l}\text { Waiting time } \\
\text { Service consumption time }\end{array}$ \\
\hline Safety Box & $\begin{array}{l}\text { Accuracy } \\
\text { Professionalism } \\
\text { Courtesy } \\
\text { Ability } \\
\text { Attentiveness }\end{array}$ & $\begin{array}{l}\text { Waiting time } \\
\text { Service consumption time }\end{array}$ \\
\hline Across Services & $\begin{array}{l}\text { Courtesy } \\
\text { Professionalism } \\
\text { Attentiveness } \\
\text { Ability } \\
\text { Accuracy }\end{array}$ & $\begin{array}{l}\text { Service consumption time } \\
\text { Waiting time }\end{array}$ \\
\hline
\end{tabular}

The data from the five individual services were additively combined to create an across-services data base. A similar factor analysis was performed on this data and the results are also presented in Table 1. The two dimensions of time and quality are also evident in the results from the across-services data.

Following the factor analysis, the factor scores were used as input to a stepwise discriminant analysis. This analysis determined the degree to which the two factors accounted for the satisfaction with each service transaction. In the first discriminant analysis, the dependent variable was the "satisfaction with the service experience" measurement and, in the second, the "satisfaction with the service accomplishment" measurement. Independent variables, in both discriminant analyses, were the two factors of time and quality.

The results of the stepwise discriminant analysis are presented in Table 2. From this table, we can see that the two factors jointly account for a significant amount of the variance of the dependent variable (the model $\mathrm{R} 2$ ranged from .17 to .34 , which are significant at the $p=.01$ level).

Of the two factors, "time" is the more important determinant of customer satisfaction. In respect to the "service experience satis- 
Table 2

Significance of Quality and Time in Satisfaction with the Banking Transaction

\begin{tabular}{|c|c|c|c|c|}
\hline \multirow{2}{*}{ Banking Transaction } & \multicolumn{2}{|c|}{$\begin{array}{c}\text { Satisfaction with Service } \\
\text { Experience }\end{array}$} & \multicolumn{2}{|c|}{$\begin{array}{c}\text { Satisfaction with Service } \\
\text { Accomplishment }\end{array}$} \\
\hline & Factor & P. $\mathrm{R}^{2}$ & Factor & P. $\mathrm{R}^{2}$ \\
\hline ATM & $\begin{array}{l}\text { Time (F2) } \\
\text { Quality (F1) }\end{array}$ & $\begin{array}{l}.27^{* *} \\
.06^{* *}\end{array}$ & $\begin{array}{l}\text { Time (F2) } \\
\text { Quality (F1) }\end{array}$ & $\begin{array}{l}.26^{* *} \\
.08^{* *}\end{array}$ \\
\hline Loan & $\begin{array}{l}\text { Time } \\
\text { Quality }\end{array}$ & $\begin{array}{l}.18^{* *} \\
.06^{* *}\end{array}$ & $\begin{array}{l}\text { Time } \\
\text { Quality }\end{array}$ & $\begin{array}{l}.21^{* *} \\
.09^{* *}\end{array}$ \\
\hline New Account & $\begin{array}{l}\text { Time } \\
\text { Quality }\end{array}$ & $\begin{array}{l}.13^{* *} \\
.06^{* *}\end{array}$ & $\begin{array}{l}\text { Time } \\
\text { Quality }\end{array}$ & $\begin{array}{l}.13^{* *} \\
.08^{* *}\end{array}$ \\
\hline $\mathrm{CD}$ & $\begin{array}{l}\text { Time } \\
\text { Quality }\end{array}$ & $\begin{array}{l}.13^{* *} \\
.11^{* *}\end{array}$ & $\begin{array}{l}\text { Quality } \\
\text { Time }\end{array}$ & $\begin{array}{l}.14^{* *} \\
.12^{* *}\end{array}$ \\
\hline Safety Box & $\begin{array}{l}\text { Quality } \\
\text { Time }\end{array}$ & $\begin{array}{l}.15^{* *} \\
.09^{* *}\end{array}$ & $\begin{array}{l}\text { Quality } \\
\text { Time }\end{array}$ & $\begin{array}{l}.11^{* *} \\
.06^{* *}\end{array}$ \\
\hline Across Services & $\begin{array}{l}\text { Time } \\
\text { Quality }\end{array}$ & $\begin{array}{l}.15^{* *} \\
.09^{* *}\end{array}$ & $\begin{array}{l}\text { Time } \\
\text { Quality }\end{array}$ & $\begin{array}{l}.13^{* *} \\
.11^{* *}\end{array}$ \\
\hline & $\begin{array}{l}{ }^{* *} \text { Significant } \\
\mathrm{P} . \mathrm{R}^{2}=\mathrm{Par}\end{array}$ & $\begin{array}{l}\text { e .01 lev } \\
\text { R-Square }\end{array}$ & & \\
\hline
\end{tabular}

areas where management may wish to concentrate its time and attention to ensure a higher degree of customer satisfaction with its banking service.

\section{Elements of the Time Factor}

Waiting Time. Waiting time needs to be shortened - or at least the impression of waiting time. Other industries make conscious efforts in this direction by, for instance, piping in music, providing reading material, having a coffee urn, a TV screen, and so forth. What can a bank do? Staggered hours for bank tellers and officers related to peak times is one obvious approach. A less obvious one would be to sort out reception areas according to the sensitivity of the particular banking transaction. Fewer people waiting makes it appear that the waiting time will be less for a given transaction. Another approach would be to emulate supermarkets and bring extra tellers or platform personnel into faction," this is true for four out of the five services and for the across-services analysis. In respect to the "satisfaction with the service accomplishment," time was the more important factor in three out of the five services and for the across-services analysis. Thus, we can conclude that both the time factor and the quality factor significantly affect customers s satisfaction, though time outweighs quality.

\section{Discussion and Recommendations for Banking}

The seven elements -waiting time, service consumption time, courtesy, attentiveness, ability, accuracy, and professionalism -which comprise the two factors of consumer satisfaction suggest the areas to which bank management needs to pay attention.

While considerable thought, not to say money and other resources, has been put into bank automation and labor saving, there are still areas of banking where the old fashioned one-on-one approach is necessary and fundamental to present and future relations to clients. We recognize the cost-effectiveness and efficiency brought about by the utilization of electronic and mail services to facilitate the use of bank products. Nevertheless, where banking requires personal attention, then it is incumbent on the bank to put its best efforts into this relationship (Bitner, Nyquist, and Booms 1985). Our seven elements suggest play whenever more than 2-3 customers begin to congregate. Related to this would be questions of bank design. Back office people in this day and age of open offices are usually quite visible to the customers. However important their tasks may be, for a waiting customer they can appear to be doing nothing to get his/ her task accomplished. So, either use these back office people to swing into action whenever queues begin to form, or hide them away, out of sight.

Service Consumption Time. The consumer has a sense of his/her own worth and does not wish to wait long for service consummation. If it seems to take too long there is an additional implication that the bank is not efficient or its representatives are not knowledgeable. Service consumption time depends not only on the customer's requirements but also on how fast or slow the provider performs. Whatever can be prepared in advance speeds up the service consumption time. Manufacturing industries have adopted the "just in time" inventory concept, to minimize costs and speed production processes. Likewise, standardized forms and procedures can be developed by banks. These could include precoding and computerized form filling, via CRTs. The representative needs a thorough grounding in the bank s products, to be able to explain quickly, efficiently, and intelligently which bank services will meet the customer's needs. 


\section{Elements of the Quality Factor}

Courtesy. Banking is a service business. It is important to impress upon employees the fact that customers create the bank's jobs. They are important and should be treated with the utmost courtesy. Address your customer by name, whenever possible.

Attentiveness. Allied to courtesy is the element of attentiveness, where the supplier is expected to give the customer complete consideration. Distractions, whether by telephone or fellow employees, detract from this consideration. When the bank representative is meeting with a customer, that customer must receive utmost attention during the course of his/her transaction.

Ability and Accuracy. Both ability and accuracy may be considered the result of employee training and experience. Good training programs take time and effort. Nevertheless, they are critical in service industries, particularly in financial matters where customers wish to feel confident about receiving the best solution to the matter under discussion. Any errors of commission and omission by the provider may undermine the confidence of the customer.

Professionalism. From the bank's perspective, a transaction may be routine between customer and representative, one of the millions that occur each working day. From the customer's viewpoint it is personal - a singular transaction. The customer wants to feel that he/she is dealing with a professional who is overseeing an important financial matter. The customer is not, after all, buying groceries. Even in a supermarket, the cashiers, let alone the managers, are dressed appropriately and act with decorum. The bank representative must appear even more professional to uphold the status and image of banking. The bank representative $s$ behavior must convey authority.

Our findings indicate a direction for action by bank management to enhance customer satisfaction in the oneon-one relationship between supplier and consumer. All too seldom does a bank actually see its customers. The mechanization of bank services has largely done away with the need for consumers to actually come to the bank. When customers do come to the bank, make sure you take care of them. The opportunity to impress a customer, face to face, comes infrequently and needs to be exploited to the full. Time spent in the face-to-face relationship packs more punch with the customer than millions of dollars spent on impersonal advertising.

\section{General Conclusions}

The application of these seven elements are not limited to banking but are generally present in marketing services. The medical field has learned to shorten waiting time by having a series of cubicles in a doctor's office in which patients wait for their examination, apart from the general waiting room. In effect, the patient's perception of waiting time has been reduced. The Disney organization has applied similar principles to its long waiting lines at Walt Disney World and Disneyland in which the patrons are in lines which move continuously forward, lessening the negative impact of the long queues for its rides. The airlines have learned to schedule flying times that are longer than needed for an actual flight so that they can report more flights arriving "on time."

Successful publisher's representatives make a courtesy call, or drop a note, to thank a professor on the adoption of a text. They also expedite the delivery of books by using courier services like UPS or Federal Express.

In retaining customer loyalty, sales representatives are designated to give special attention to valuable customers. The representatives will give their customers advance notice of impending sales, inform them of the arrival of new inventory, and even open the store at non-scheduled hours for escorted shopping expeditions.

Service firms are increasingly aware their success depends, in large measure, on the ability of their employees. As a consequence, companies devote more of their budgets to training programs today to ensure their representatives are knowledgeable and competent.

Computerization in service industries, notably in the medical field, has increased accuracy of record-keeping.

Professionalism is conveyed through a variety of devices. Employees in contact with customers are given desks, phone lines, calling cards, and titles . all to foster an impression of professionalism in their customers.

All seven of these elements we have enumerated are part and parcel of an overall strategy to achieve customer satisfaction in any service industry.

Acknowledgments: The authors wish to thank Dr. Eric R. Reidenbach for helpful comments on an earlier draft and BankAtlantic for funding our data collection.

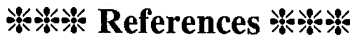

1. Barker, Tansu and Martin L. Gimple, "Differentiating a Service Business:Why and How," Journal of Small Business Management, Vol. 20, April, pp. 1-7, 1982.

2. Berry, Leonard L., "The Time Buying Consumer," Journal of Retailing, Vol. 56, Winter, pp. 58-69, 1980.

3. Berry, Leonard L., Valarie A. Zeithaml, and A. Parasuraman, "Quality Counts n Services Too!," Business Horizons, Vol. 28, May-June, pp. 44-52, 1985. 
4. Bitner, Mary J., Jody D. Nyquist, and Bernard H. Booms, "The Critical Incident as a Technique for Analyzing the Service Encounter," Services Marketing in a Changing Environment, Thomas M. Bloch, Gregory D. Upah, and Valarie A. Zeithaml, eds., Chicago: American Marketing Association, pp.48-51, 1985.

5. Blackwell, Roger D. and Margaret Hanke, "The Credit Card and the Aging Baby Boomers," Journal of Retail Banking, Vol. 9, No. 1, Spring, pp. 17-25, 1987.

6. Cravens, David W., Terry E. Dielman, and C. Kent Harrington, "Using Buyers' Perceptions of Service Quality to Guide Strategic Development," Proceedings of the American Marketing Association, Chicago: American Marketing Association, pp. $297-$ 301, 1985.

7. Crosby, Lawrence A. and Nancy Stephens, "Effects of Relationship Marketing on Satisfaction, Retention, and Prices in the Life Insurance Industry," Journal of Marketing Research, Vol. 24, November, pp. 404-411, 1987.

8. Davis, Duane and Gordon Paul, "Identifying Components of Service Quality:The Case of the Health and Fitness Industry," Proceedings of the American Marketing Association, Chicago: American Marketing Association, pp. 82-87,1987.

9. Day, Ellen and Stephen B. Castleberry, "Defining and Evaluating Quality:The Consumer s View," Advances in Consumer Research, Richard J. Lutz, ed., Vol. 13, pp. 94-98, 1986.

10. Fisk, Raymond P., "Postchoice Evaluation: An Equity Theory Analysis of Consumer Satisfaction/Dissatisfaction with Service Choices," Unpublished Ph.D. dissertation, Arizona State University, 1980.

11. Feinholz, Linda S., "Using Consumer Evaluations of Health Care Quality to Identify Marketing Opportunities," Health Marketing Quarterly, Vol. 3, No. 4, Summer, pp. 73-81, 1986.

12. Garfein, Richard T., "A Company Study Evaluating the Impact of Customer Service Delivery Systems," Journal of Services Marketing, Vol. 1, Fall, pp.19-25, 1987.

13. Gronroos, Christian, "A Service Quality Model and Its Marketing Implications," European Journal of Marketing, Vol. 18, No. 4, pp. 36-44,1984.

14. Gwin, John M. and John H. Lindgren, "Reaching the ServiceSensitive Retail Consumer," Journal of Retail Banking, Vol. 8, No. 3, Fall, pp. 36-42, 1986.

15. Kim, Suk H., Edward J. Farragher, and Henry J. Guithues, "Some Factors Affecting Overall Satisfaction of Michigan Bank Customers," Baylor Business Studies, Vol. 10, No. 2, May-July, pp. 55-60, 1979.

16. Koehn, Hank E., :"The Baby Boom Market: 2001,": Journal of Retail Banking, Vol. 8, No. 4, Winter, pp. 29-32, 1986-87.

17. Kotler, Philip, Marketing Management: Analysis, Planning, Implementation, and Control, 7th ed., Englewood Cliffs, NJ: Prentice Hall, 1991

18. Lane, Paul M.,"Women in Time: An Application of a Classification System for the Fourth Dimension," Strategic Issues in a Dynamic Marketing Environment: Proceedings of the Annual Meeting of the Southern Marketing Association, John H. Summey and Paul J. Hensel, eds., Atlanta, GA, November 2-5, pp. 216-227, 1988.

19. Lane, Paul M., Carol J. Kaufman, and Jay D. Lindquist,"More Than 24 Hours a Day," Proceedings of the American Marketing Association, Winter Educators" Meetings, Chicago: American Marketing Association, 1989.

20. Larroche, Michel and Thomas Taylor, "An Empirical Study of Major Segmentation Issues in Retail Banking," International Journal of Bank Marketing, Vol. 6, No. 1, pp. 31-48, 1988.
21. Likert, Rensis, Sydney Roslow and Gardner Murphy, "A Simple and Reliable Method of Scoring the Thurstone Attitude Scales," Journal of Social Psychology, Vol. 5, pp. 228-238, 1934.

22. Lovelock, Christopher H. and Robert E. Young, "Look to Consumers to Increase Productivity," Harvard Business Review, Vol. 57, May/June, pp. 168-178, 1979.

23. Maister, David H., "The Psychology of Waiting Lines," The Service Encounter: Managing Employee/Customer Interaction in Service Businesses, Lexington, MA: Lexington Books, pp. 113-123, 1985.

24. Parasuraman, A., Valarie A. Zeithaml, and Leonard L. Berry, "A Conceptual Model of Service Quality and Its Implications for Future Research," Journal of Marketing, Vol. 49, Fall, pp. 41-50, 1985.

25. Pollock, Alex J., "Banking: Time to Unbundle the Services?" LongRange Planning, Vol. 18, No. 1, pp. 36-41, 1985.

26. Schoell, William F. and Joseph P. Guiltinan, Marketing: Concepts and Practices, 4th. Annotated Instructor's edition, Boston: Allyn and Bacon, 1990.

27. Stanley, Thomas J., George P. Moschis, and William D. Danko, "Financial Service Segments: The Seven Faces of the Affluent Market," Journal of Advertising Research, Vol. 27, No. 4, August/September, pp. 52-67, 1987.

28. Zeithaml, Valarie A., "How Consumer Evaluation Processes Differ Between Goods and Services," in Marketing of Services, James H. Donnelly and William R. George, eds., Chicago: American Marketing Association, pp. 186-190, 1981.

29. Zeithaml, Valarie A., A. Parasuraman, and Leonard L. Berry, "Problems and Strategies in Services Marketing," Journal of Marketing, Vol. 49, Spring, pp. 33-46, 1985. 